\title{
C-43 THE ATLANTIC DEEPWATER BETWEEN TANGER AND SAFI, GEOLOGY AND PLAY CONCEPTS
}

MOHAMED HSSAIN and MHAMMED EL MOSTAINE ONAREP, PO Box 8030, Rabat, Morocco

\section{INTRODUCTION}

The study areas located in the northern part of Morocco extend along the western cost between the cities Safi and Tangier. The continental platform covers an area of about $24,000 \mathrm{sq} . \mathrm{km}$; however, the petroleum exploration zone extends in deep water under $200 \mathrm{~m}$ isobath (Fig. I).

\section{Regional Geological setting and history}

The areas of interest, is a part of the Atlantic continental margin, which are made of numerous of sedimentary coastal basins. Graben evolution and deposition of continental red beds, which began in the Triassic, mark the initiation of the Atlantic rift. Broad down warping and development of deep seated extensional fault began in the late Triassic and affect subsequent sedimentation.

Sedimentation, within the northwestern zone, is affected by the proximity of the nappes derived from the central Rif fold belt. The area is comprised of highly folded flysch. The Rharb basin is partly situated along the front of the, external Rif nappes, represents the foredeep basin of the Rif complex fold belt. The basin fill is represented by sediments ranging in age from Paleozoic to Tertiary. The Tertiary Nappe, which overlies the Paleozoic and Mesozoic succession, dips northward. Miocene faults terminate at the base of the nappes. Post-nappe movements affected the Miocene and younger sediments by compaction and loading gravity tectonics. Tertiary alpine orogenic movements dominated the structural complexity of the offshore and adjacent onshore area (Fig. 2).

\section{Seismic data base}

Bosco acquired the first seismic survey in the continental platform in 1970.

The program covers about $1950 \mathrm{~km}$ of 4 fold of seismic lines between Rabat and Tangier.

GSI hoot, for BURMAH OIL LTD, $2400 \mathrm{~km}$ of seismic profiles in the same block of BOSCO during the period $1973-1974$ and 1950 kin in the area between Rabat and E1 Jadida.

Seismic Profilers shoot $915 \mathrm{~km}$ of speculative seismic lines in the Safi offshore in 1983.

PCIAC acquired about $3422 \mathrm{~km}$ of seismic lines in the areas between Safi and Kenitra in the period 1986-1987.

GECO recorded for JNOC $1000 \mathrm{~km}$ of seismic lines in the southern portion of the area in 1987.

Texaco acquired $1480 \mathrm{~km}$ of 2-D data in central basin1991(Fig.3).

\section{Drilling activity}

The study area is still a frontier zone. Only one well was drilled in the northern part in the offshore of Larache City. The well (LAR-1A) was drilled to test a rollover structure within the Miocene Post-nappe. It was stopped at $2399 \mathrm{~m}$ in the post Nappe Messinian shale.

\section{Petroleum potential}

In assessing the petroleum potential of a virgin exploration area, as it is the case in Moroccan water depth. It is useful to refer to adjacent onshore and offshore provinces with histories of hydrocarbon exploration. Having this in mind, and using limited data from the already drilled areas of Moroccan Atlantic continental margin, an attempt is made to discuss the hydrocarbon habitat of the virgin Moroccan Atlantic deep water offshore sedimentary sequences. 


\begin{abstract}
Source rock
The hydrocarbon of western part of the Moroccan deep water is supported by the presence of sediments rich in organic matter within the Albian, Cenomano-Turonian stratigraphic interval and also Oligocene and Middle Miocene. The dark green and brown marls of Aptian-Albian interval at site 369 (fig .4)show high enrichment in organic matter with TOC values ranging from 1 to $5 \%$ while pelagic marls at site 370 , show Toc's up to $3 \%$

(J.P Herbin, 1986). High TOC values were also encountered in the main clay of Oligocene-Middle Miocene (1.6 to $6 \%$ ) series at Marcan-01, MO-08, Layoune 8-1 and 8-2 wells. Marine claystones of the Cenomanian Turonian sequence contain 7 to $19 \%$ TOC.

\section{Reservoir rock}

In the Rharb offshore basin, the Cretaceous series seem to be the same as those, which found in the onshore area. The Cretaceous detrital facies encountered in the El Menzeh area have excellent petrophysical characteristics ( $21 \%$ porosity and $117 \mathrm{md}$ of permeability). The Jurassic formations, which produced hydrocarbon in the Prerif Ridges, are the most attractive plays in this zone. The Neogene succession shows many porous intervals, the Early Miocene compose of sandy limestones displayed good reservoir characteristics in the Prerif Ridges and in the Rharb basin.

The DSDP wells $(115,116$ and 137) show the presence of thin alternating chalk/marl ooze an turbidites layers deposited in the Late Miocene or Early Pliocene (fig.5) which form plays in th areas between Safi and Kenitra. To the south of Safi area, the Late Cretaceous marls are interbeded with sandstones and limestones intervals with porosity values of 12 to $25 \%$. Beyond the Jurassic carbonate shelf edge, sand and sandy to conglomeratic beds at the base of the Oligocene or those of Middle to Late Miocene constitute the best Tertiary reservoir with porosity ranging from 20 to $30 \%$.

\title{
Concepts of Exploration
}

In the Safi-Casa segment, the developed Exploration play concept is the Aptian turbiditic sandstones, which is $550 \mathrm{~m}$ thick. It's characterised by clastics, with a sand bar at the top of the sequence. However, in the offshore area of the segment, and at least in the Agadir offshore, very little pre-middle Aptian sediments were deposited at the vicinity of Marcan-01 well. Low Cretaceous sediments were probably deposited and then eroded by Aptian submarine currents and redeposited in deep sea area as a fan complex at the foot of the Jurassic escarpment. In this kind, it is interesting to realise that in site 370 of the DSDP leg 41, $800 \mathrm{~m}$ of Lower Cretaceous distal turbidites were encountered, it is therefore expected that thickness and better quality proximal sandstone can be found at the base of the continental slope.

The halokinesis produced by Triassic/Liassic evaporates, which started as early as Middle Jurassic, controlled sedimentation of Cretaceous turbiditic series within the deepwater zone. Th movement resulted in the formation of salt domes and salt injection structures (fig.6).

In the deep sea of the Rharb basin, the Mesozoic passive margin sediments and the forland basin, which extend below the Rif thrust belt are the moose promising for hydrocarbon exploration. The main concept of exploration in this zone is the up deep Cretaceous and old stratigraphic trap beyond the Prerif accretionary wedge and salt dome related structuration.

Please note that this abstract has been retyped and the figures are scanned, as it was not received in a digital format. EAGE cannot be held responsible for any typing errors that may occur nor for any results that might arise from scanning the figures in this text. 




FIG 1: $L$ ocation $m$ ap of the study a rea

\begin{tabular}{|c|c|c|c|c|c|c|}
\hline \multirow{2}{*}{\multicolumn{2}{|c|}{\begin{tabular}{|c|} 
AGE \\
NEOGENE \\
PALEOG.
\end{tabular}}} & LTHOLOGY & $\begin{array}{l}\text { SOURCE } \\
\text { ROCK }\end{array}$ & KRESERVOIR & SEAL & PRODUCTION \\
\hline & & $=$ & $\square$ & $\hookrightarrow$ & $\square$ & 常 $0_{\text {Prerif }}^{\text {Rhar }}$ \\
\hline \multirow{2}{*}{ 椞 } & U. & 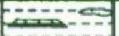 & & $\square$ & $\square$ & \\
\hline & M. & ans....... & $\square$ & $\square$ & $\square$ & \\
\hline \multirow{3}{*}{$\frac{\dot{3}}{3}$} & U. &  & $\square$ & \multirow{2}{*}{ • } & \multirow{2}{*}{$\square$} & \multirow[t]{2}{*}{ O Essaouira } \\
\hline & M. & 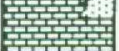 & \multirow{2}{*}{$\square$} & & & \\
\hline & L. & 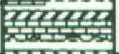 & & $\square$ & ש & - Prerif \\
\hline \multicolumn{2}{|c|}{ TRIAS } & $\frac{1}{1+k}$ & $c=1$ & $\square$ & $\square$ & Essaouira \\
\hline \multirow{2}{*}{ 远 } & L. & & \multirow[t]{2}{*}{$\square$} & \multirow{2}{*}{ 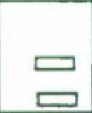 } & \multirow[t]{2}{*}{$\square$} & \multirow[t]{2}{*}{$\circ \quad$ Sidi Fili } \\
\hline & E. &  & & & & \\
\hline 좀 & \begin{tabular}{|l|} 
U. \\
M. \\
L.
\end{tabular} & 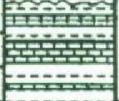 & $\square$ & 口 & $\square$ & \\
\hline \multicolumn{2}{|c|}{ SILUR. } & $=:=$ & $\square$ & & \multirow[t]{2}{*}{$\square$} & \\
\hline \multicolumn{2}{|c|}{ ORDOV. } & P & $\square$ & $\square$ & & \\
\hline \multicolumn{2}{|c|}{ CAMB. } & 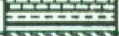 & & & & \\
\hline \multicolumn{2}{|c|}{ PREC. } & 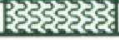 & & & & \\
\hline
\end{tabular}

Fig. 2: Stratigraphic column of the northern part of the Morocan Adlantic marein 


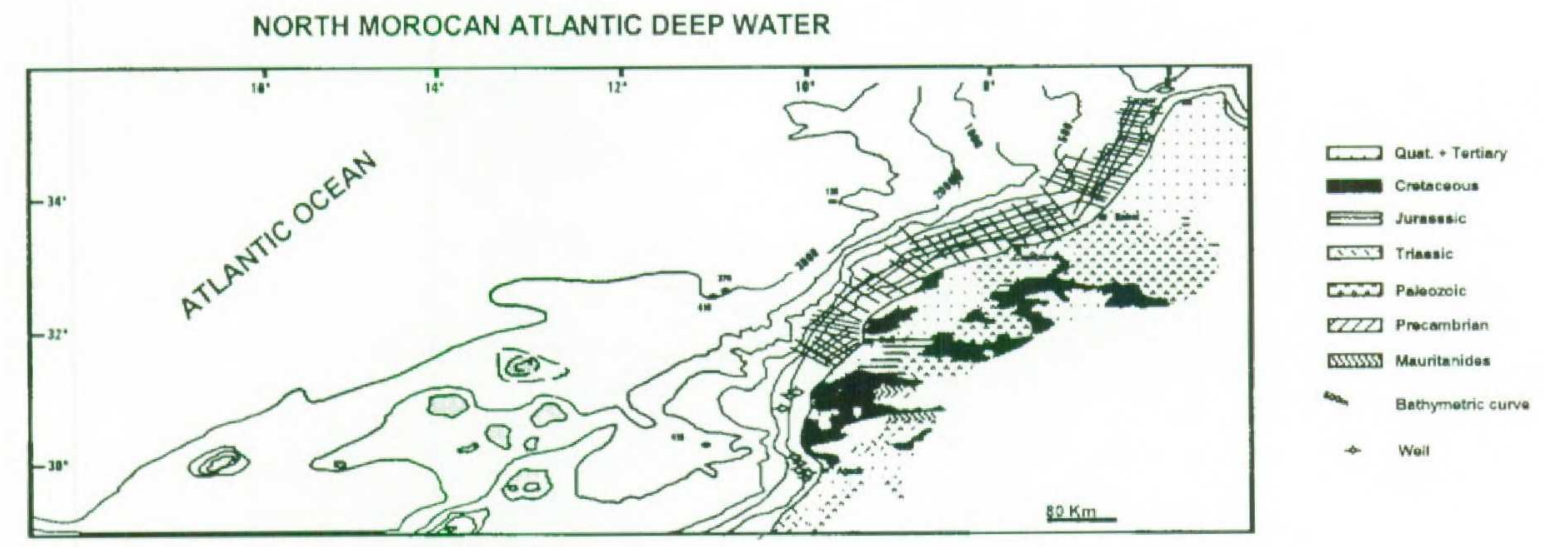

Fig. 3: Seismic and Well data

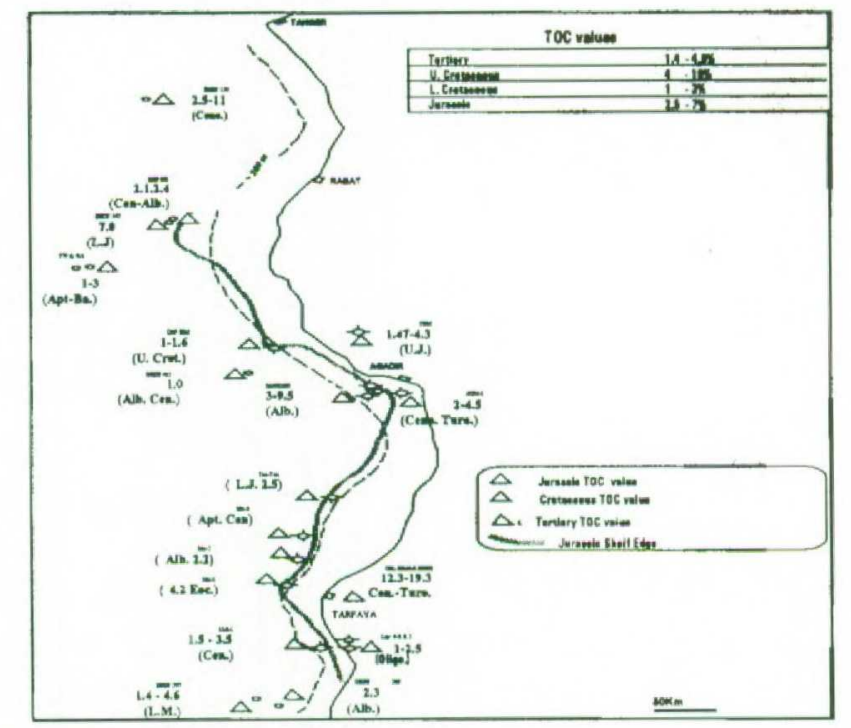

Fig.4: Defined source rocks within the Morocan 


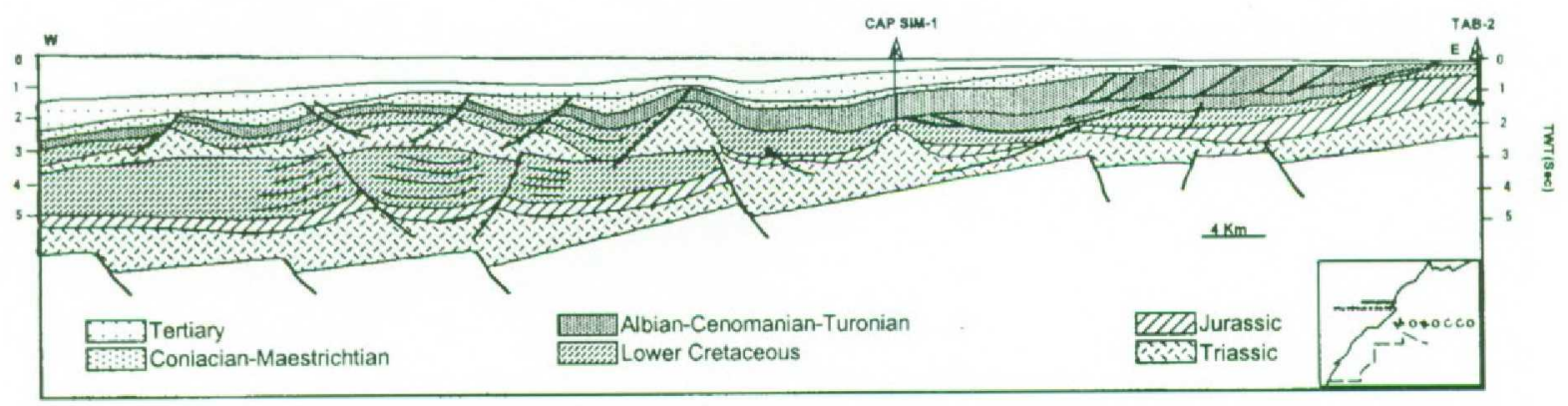

Fig.6 : Geoseismic Section in the Essaouira Basin showing the allochtnous Triassic salt and related traps 


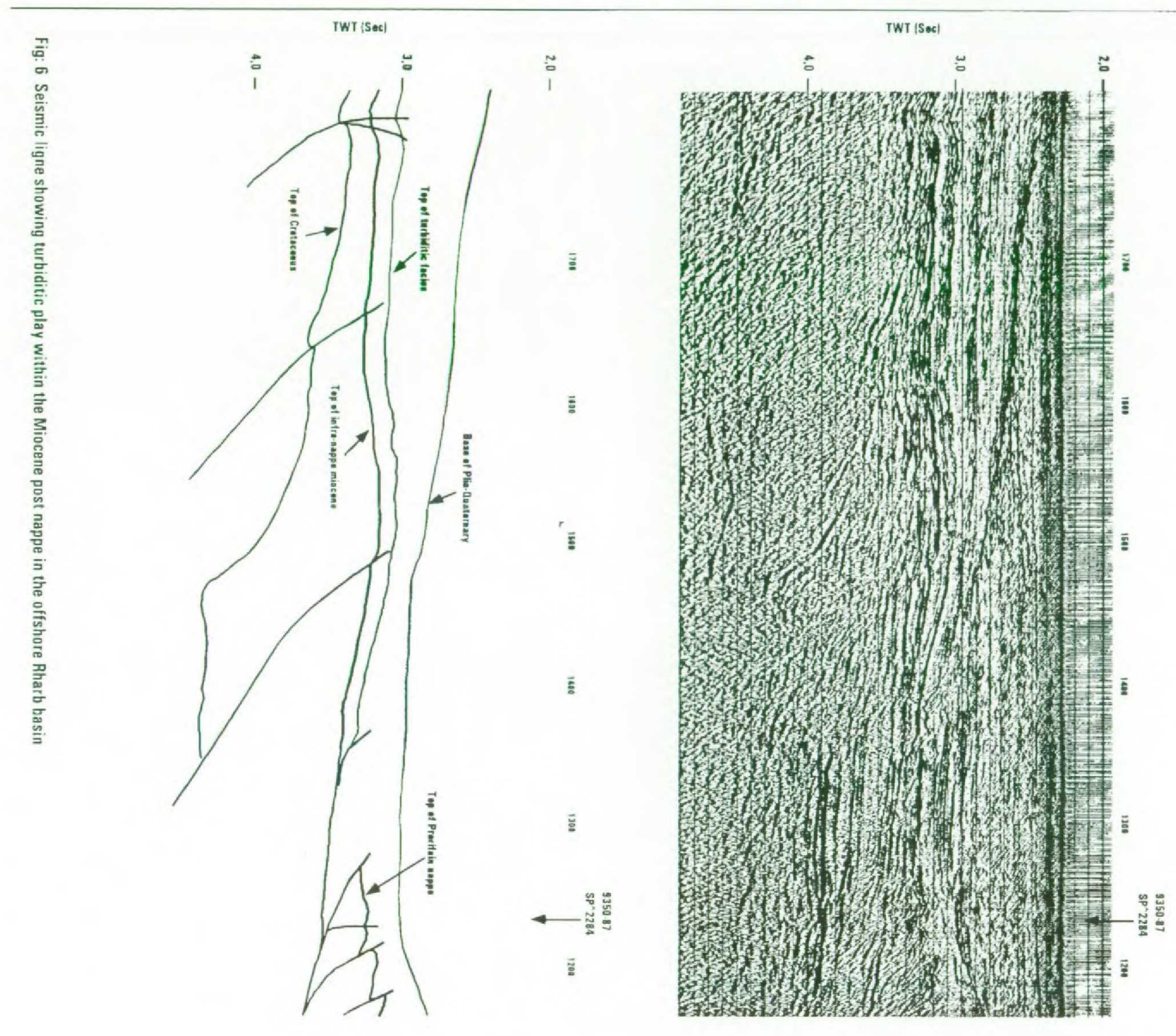

